Article

\title{
Abrasion-Resistant and Temperature Control of Lining Concrete for Large-Sized Spillway Tunnels
}

\author{
Qiang Yao ${ }^{1,2} \mathbb{C}$, Shunchao $\mathrm{Qi}^{1,2}$, Faming $\mathrm{Wu}^{1,2}$, Xingguo Yang ${ }^{1,2}$ and Hongtao $\mathrm{Li}^{1,2, *}$ \\ 1 State Key Laboratory of Hydraulics and Mountain River Engineering, Sichuan University, \\ Chengdu 610065, China; yaoqiang777@scu.edu.cn (Q.Y.); shunchaoqi@scu.edu.cn (S.Q.); \\ eapoltrzp@gmail.com (F.W.); 89022251@scu.edu.cn (X.Y.) \\ 2 College of Water Resource and Hydropower, Sichuan University, Chengdu 610065, China \\ * Correspondence: htl@scu.edu.cn
}

Received: 26 August 2020; Accepted: 26 October 2020; Published: 28 October 2020

\begin{abstract}
With regard to the high anti-scouring and abrasion-resistant performance requirements and great temperature control difficulties of lining concrete for large-sized spillway tunnels, in this study, a performance test was conducted on anti-scouring and abrasion-resistant concrete. The finite element method was used to analyze the temperature change rules of sidewall $\mathrm{C}_{90} 50$ (design strength of concrete is $50 \mathrm{MPa}$ at 90 days) lining concrete for the spillway tunnel. Further, a new cooling measure was proposed for adopting "early-throughput, high-flow and short-duration". As indicated by the results of this study, fly ash could reduce water consumption and micro-cracks via its "morphological effect". Silica fume could improve the early strength of cement concrete and make up for the strength loss caused by fly ash. Polyvinyl alcohol (PVA) fiber could enhance concrete durability. The doping of these three additives reinforced the strength and abrasion resistance of concrete. The results showed that the temperature of the lining concrete presented a change trend of "rapid increase first, followed by a slow decrease". The peak temperature was reached roughly 2 days after casting. In addition, properly increasing throughput flow or decreasing throughput temperature in the early stage of casting could significantly reduce the highest temperature and maximum temperature difference of concrete. Based on the results from the numerical simulation of temperature control effect, it was proposed to adopt "early-throughput, high-flow, and short-duration" for temperature control and cracking prevention. Specifically, within 2 days after casting, cooling water at roughly $12{ }^{\circ} \mathrm{C}$ was guided in at a flow of approximately $3.5 \mathrm{~m}^{3} / \mathrm{h}$. Within $3-7$ days after casting, river water at around $17^{\circ} \mathrm{C}$ was guided in at a flow rate of approximately $1.8 \mathrm{~m}^{3} / \mathrm{h}$. After 7 days, the cooling effect can be well achieved by only using the surface flowing water for curing. According to the field monitoring data, the changes in measured temperature were basically consistent with those from numerical simulations, and detection on the temperature of the sidewall lining concrete showed that a qualification rate of $>91 \%$ was satisfactorily obtained by using the proposed approach.
\end{abstract}

Keywords: spillway tunnel; concrete; anti-scouring and abrasion-resistant; temperature control; crack prevention measure

\section{Introduction}

In China, large-sized hydropower projects are mainly distributed in western alpine and gorge regions. Restricted by topography, geology and other conditions, there are numerous spillway tunnels of large-size, high single-tunnel discharge with high flow rate. For example, under the verified flood level, the spillway tunnel of Dagangshan hydropower station has a maximum flood discharge capacity of $3352 \mathrm{~m}^{3} / \mathrm{s}$ and the highest flood discharge flow rate of approximately $42 \mathrm{~m} / \mathrm{s}$. The average annual service time of the spillway tunnel is more than $2000 \mathrm{~h}$, and the high frequency of use ranks the top 
of the same type of power stations in China. Therefore, higher requirements are put forward for the anti-scouring and abrasion resistance of the concrete in the spillway tunnel. Therefore, anti-scouring and abrasion-resistant concrete is generally adopted in construction; however, this gives rise to a series of problems, such as high temperature control requirements and difficult crack control. In the case of temperature cracking being accompanied with long-term scouring by high-velocity water flows carrying sediments, it will further result in cavitation erosion and seriously threaten the safe and stable operation of spillway tunnels and hydropower stations, not to mention the extremely high cost of repair. In this sense, studying the anti-scouring and abrasion-resistant performance and temperature control technology of lining concrete for large-sized spillway tunnels is of vital theoretical significance and practical value.

Generally, anti-scouring and abrasion-resistant concrete is used for spillway tunnel lining and the performance of this type of concrete mixed with fly ash, silica fume and fiber has been extensively investigated. Turk et al. [1] found that class F fly ash concrete with up to $15 \%$ cement replacement was acceptable for structural applications of abrasion erosion resistance. Naik et al. [2] and Ukita et al. [3] reported that if $15 \%$ of cement was replaced with fly ash, the abrasion increased with the fineness of fly ash. However, with a fly ash content of $30 \%$, the abrasion resistance of concrete turned out to be lower than that without fly ash. Siddique [4] found that abrasion resistance could be improved approximately by $40 \%$ when $40 \%$ fine aggregate was replaced with fly ash. Yen et al. [5] concluded that if the replacement percentage exceeded $15 \%$, fly ash concrete showed lower resistance to abrasion-erosion compared to non-fly ash concrete. The utilization of silica fume was a typical strategy to improve the abrasion erosion resistance of concrete [6-8]. However, the amount of silica fume should be considered with caution as excessive silica fume might lead to cracks. Ghafoori and Diawara [9] found that the resistance to wear of concrete containing silica fume as a fine aggregate replacement was consistently better with increasing amounts of silica fume up to $10 \%$. Zeng and Chung [10] found the abrasion resistance of concrete was improved by the addition of silica fume due to the increase in tensile modulus. Liu [11] reported that the abrasion resistance increased with respect to the increase in silica fume addition. For concrete with a 1-mm width surface crack, and if the water flow impinged directly into the crack, the abrasion rates were nearly $13 \%$ and $25 \%$, respectively, higher than that of the intact mixture. The toughness and durability of concrete can be significantly improved by the addition of fibers. Sonebi and Khayat [12] found that the incorporation of latex and steel fiber did not improve significantly the mechanical and hydraulic abrasion resistance of such high-strength concrete (HSC). Nanni [13] found that the addition of steel or synthetic fibers did not cause any appreciable change in the abrasion resistance of concrete. Siddique et al. [14] found that the inclusion of polyester fibers in high volume fly ash concrete (HVFA) improved abrasion resistance. Gong et al. [15] studied the ultimate bearing capacity of the conventional reinforced concrete $(\mathrm{RC})$ and the steel fiber-reinforced concrete (SFRC) joints under different loading conditions with a special attention on the corresponding cracking process. The experimental results demonstrated that the peak bearing capacity of the SFRC joints was slightly higher than that of the RC joints.

The temperature control and crack prevention problems with large-volume lining concrete for spillway tunnels have always been a focus and difficulty of related studies. Taking the water supply tunnel project of the Three Gorges Dam's permanent ship lock as an example, based on the measurements of temperature and stress, Fang et al. [16] carried out the finite element simulation for analysis of the temperatures and stresses in sidewall and top arch in the construction period. Duan et al. [17] conducted a field temperature test on both casting temperature-controlled concrete and conventional concrete and analyzed the distribution of the temperature field in the lining concrete and its change over time. Wang et al. [18] simulated the effects of crack prevention under multiple temperature control measures. Duan et al. [19] used a self-coded program called SPS_FET2D to simulate the construction process of the Xiaolangdi Spillway Tunnel Project and discussed the cause and mechanism of cracking. Wu et al. [20] explored the effect of throughput duration on pipe cooling via analyzing the data from the Xiluodu Diversion Tunnel Project. Guo et al. [21] probed into the 
throughput cooling effect of lining concrete of different thicknesses. Chen et al. [22] investigated the effects of cavern and surrounding rock temperature on the temperature and thermal stress of lining concrete for spill tunnels. Feng et al. [23] studied the effects of the final adiabatic temperature rise magnitude and its rate of concrete on the temperature and thermal stress field in the lining concrete. Using the Sanbanxi Spillway Tunnel Project as an example, Zhao et al. [24] explored the variations of temperature field and thermal stress redistribution in sidewall lining concrete and investigated the initiation and development processes of cracks.

This study selected the spillway tunnel of the Dagangshan Hydropower Station as a case study. Laboratory tests were conducted on the anti-scouring and abrasion-resistant performance of the lining concrete, from which the optimized contents of fly ash, silica fume and PVA fiber were determined. Meanwhile, concrete temperature control numerical simulations were performed to investigate the variations of temperature field in the anti-scouring and abrasion-resistant concrete under different throughput conditions. It is also proposed to adopt "early-throughput, high-flow and short-duration" for temperature control and cracking prevention. The effect of throughput cooling was analyzed according to temperature control monitoring data in the field. The presented analysis of experimental data, together with the proposed strategy for temperature control offered, reference information for similar projects.

\section{Anti-Scouring and Abrasion-Resistant Performance Test on Concrete}

\subsection{Project Overview}

Dagangshan Hydropower Station is the 14th cascade hydropower station planned to be built on the main stream of the Dadu River. The main body of the dam is a concrete double-curvature arch dam with a maximum height of $210 \mathrm{~m}$ and the total installed capacity is 2.6 million $\mathrm{kW}$, as shown in Figure 1 . Its spillway tunnel project is arranged on the right bank of the Dadu River and consists of an intake, trunk, outlet and downstream protection project. Its trunk is a free-flow tunnel of one-slope mode with a tunnel length of $1077.50 \mathrm{~m}$, a starting-point bottom elevation of $1098.32 \mathrm{~m}$ and a longitudinal gradient $\mathrm{i}=0.1039$; its section adopts a circular-arch straight wall form and has a net section size of 14.00-16.00 $\mathrm{m} \times 18.00-20.00 \mathrm{~m}$ (width $\times$ height), as shown in Figure 2. Under the verified flood level, it has a maximum flood discharge capacity of $3352 \mathrm{~m}^{3} / \mathrm{s}$ and the highest flood discharge flow rate of approximately $42 \mathrm{~m} / \mathrm{s}$. Its sidewall uses $\mathrm{C}_{90} 50$ anti-scouring and abrasion-resistant concrete, with an engineering volume of $34,300 \mathrm{~m}^{3}$. In this case, the working conditions of high hydration heat, high heat production, high flow rate and high flow and the problem of hydration heat have imposed relatively high requirements on the anti-scouring and abrasion-resistant performance, as well as temperature control and crack prevention technology of lining concrete for spillway tunnels. With regard to the high anti-scouring and abrasion-resistant performance requirements and great temperature control difficulties of lining concrete for large-sized spillway tunnels, these two issues were investigated by experimental and numerical simulation methods, respectively. Material test, numerical simulation and other methods were used to study the anti-scouring and abrasion-resistant performance and temperature control technology of concrete for the spillway tunnel.

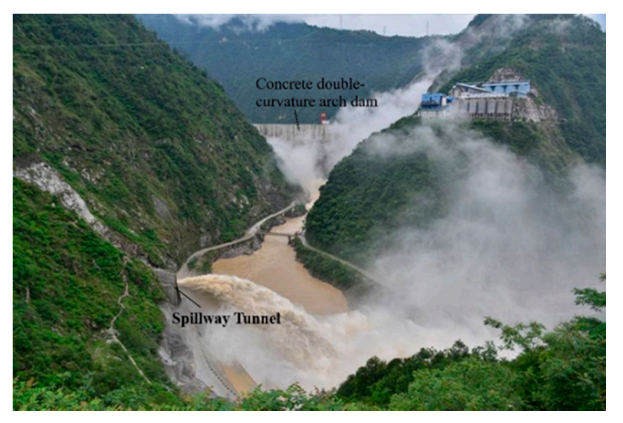

Figure 1. Three-dimensional rendering of Dagangshan Hydropower Station. 


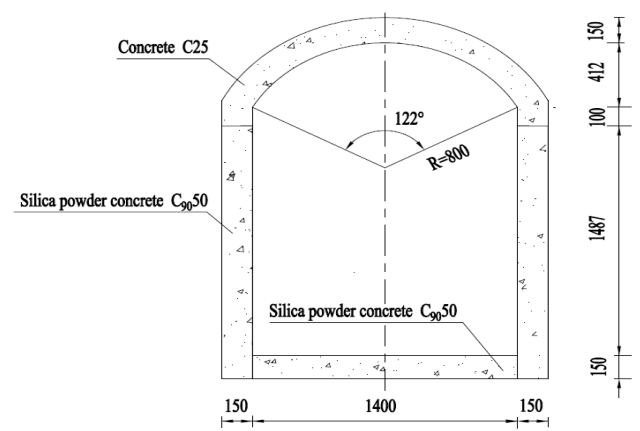

Figure 2. The type and size of lining concrete of spillway tunnel section (unit: $\mathrm{cm}$ ).

\subsection{Materials, Mix Proportions, and Test Method}

A performance test was conducted on silica fume concrete and silica fume + PVA fiber concrete of different mix proportions, and the mix proportion parameter was optimized for anti-scouring and abrasion-resistant concrete according to the test results. Finally, the mix proportion of the anti-scouring and abrasion-resistant concrete used during construction was determined.

\subsubsection{Materials}

The chemical compositions of the cement, fly ash and silica fume are listed in Table 1 . The polyvinyl alcohol fiber (PVAF) had a density of $1.28 \mathrm{~g} / \mathrm{cm}^{3}$, a tensile strength of $1565 \mathrm{MPa}$, an elastic modulus of $38.0 \mathrm{GPa}$ and an elongation at break of $8.0 \%$, which was thus characterized by high strength and high elastic modulus. The dosages of the JM-PCA (a type of polycarboxylic acid high-performance water-reducing agent) and NOF-AE (a type of air-entraining agent adopted) in the test were $0.8 \%$ and $0.4 / 10,000$, respectively. The coarse and fine aggregates were produced artificially by Gezhouba Aggregate Plant, Dagangshan Hydropower Station. The fine aggregate had a fineness modulus of 2.64 and an average particle size of $0.388 \mathrm{~mm}$. The coarse aggregate had an elongated and flaky particle content in the range $0.4-3.3 \%$ and a crushing index of $15.5 \%$. The strength performance of artificial aggregate was relatively satisfactory.

Table 1. Chemical compositions of cement, fly ash and silica fume (\%).

\begin{tabular}{cccccccc}
\hline Materials & $\mathrm{SiO}_{2}$ & $\mathrm{Fe}_{2} \mathrm{O}_{3}$ & $\mathrm{Al}_{2} \mathrm{O}_{3}$ & $\mathrm{CaO}$ & $\mathrm{MgO}$ & $\mathrm{SO}_{3}$ & Loss of Ignition \\
\hline Cement & 20.87 & 4.80 & 3.97 & 61.78 & 4.04 & 2.28 & 0.79 \\
Fly ash & 53.71 & 9.72 & 22.94 & 7.94 & 2.28 & 0.35 & 2.33 \\
Silica fume & 95.86 & 0.14 & 0.30 & 0.98 & 0.35 & - & 1.72 \\
\hline
\end{tabular}

\subsubsection{Mixture Proportions}

Raw material was used to verify various tests. The mix proportion parameters of anti-scouring and abrasion-resistant concrete, including water-cement ratio, water, cement, fine aggregates and coarse aggregates, were firstly optimized based on analyses of the experimental results, as shown in Table 2. On the basis of indoor tests, the construction mix proportion was further optimized through field trial mixing, and the corresponding concrete performance test was carried out, as shown in Tables 3 and 4. In order to further study the influence of fly ash, silica fume and PVA fiber on the behavior of abrasion-resistant concrete, eight batches of concrete mixtures were made for testing, and the mixture details are listed in Table 2. They can be broadly divided into three groups: F10S5P0, F15S5P0 and F20S5P0 for the first group; F20S5P0, F20S7P0 and F20S9P0 for the second group; F20S5P0.8, F20S5P0.9 and F20S5P1.0 for the third group. Here, " $\mathrm{F}$ ", "S" and " $\mathrm{P}$ " in the notations represent the mixtures containing "fly ash", "silica fume" and "PVA fiber", respectively. The numbers following " $\mathrm{F}$ ", "S" and " $\mathrm{P}$ " represent the mass percentages of fly ash, silica fume and PVA fiber in the concrete mixture. The water to binder ratio for all the eight batches was maintained at 0.40 . Water-reducing admixture of JM-PCA and air-entraining admixture of NOF-AE had the dosage of $0.8 \%$ and $0.004 \%$, respectively. The construction mix proportions of two graded C 9050 fly ash and silica fume concretes and their performances are listed in Tables 3 and 4. 
Table 2. Mix proportion of concrete (unit: $\mathrm{kg} / \mathrm{m}^{3}$ ).

\begin{tabular}{|c|c|c|c|c|c|c|c|c|c|c|}
\hline Mixture No. & Water-Cement Ratio & Water & Cement & Fly Ash & Silica Fume & PVA Fiber & Fine Aggregates & Coarse Aggregates & Water Reducing Agent & Air Entraining Agen \\
\hline F10S5P0 & 0.40 & 128 & 272 & 32 & 16 & 0 & 755 & 1370 & 2.56 & 0.0128 \\
\hline F15S5P0 & 0.40 & 130 & 276.25 & 32.5 & 16.25 & 0 & 755 & 1370 & 2.60 & 0.013 \\
\hline F20S5P0 & 0.40 & 132 & 280.5 & 33 & 16.5 & 0 & 755 & 1370 & 2.64 & 0.0132 \\
\hline F20S7P0 & 0.40 & 128 & 233.6 & 64 & 22.4 & 0 & 755 & 1370 & 2.56 & 0.0128 \\
\hline F20S9P0 & 0.40 & 128 & 227.2 & 64 & 28.8 & 0 & 755 & 1370 & 2.56 & 0.0128 \\
\hline F20S5P0.8 & 0.40 & 140 & 262.5 & 70 & 17.5 & 0.7 & 755 & 1370 & 2.80 & 0.014 \\
\hline F20S5P0.9 & 0.40 & 144 & 270.0 & 72 & 18.0 & 0.9 & 755 & 1370 & 2.88 & 0.0144 \\
\hline F20S5P1.0 & 0.40 & 148 & 277.5 & 74 & 18.5 & 1.1 & 755 & 1370 & 2.96 & 0.0148 \\
\hline
\end{tabular}

Table 3. Construction mix proportion of two graded $\mathrm{C}_{90} 50$ fly ash and silica fume concrete (unit: $\mathrm{kg} / \mathrm{m}^{3}$ ).

\begin{tabular}{|c|c|c|c|c|c|c|c|c|c|c|c|c|}
\hline \multirow{2}{*}{$\begin{array}{l}\text { Construction } \\
\text { Method }\end{array}$} & \multirow{2}{*}{$\begin{array}{c}\text { Preparation } \\
\text { Strength (MPa) }\end{array}$} & \multirow{2}{*}{$\begin{array}{l}\text { Water-Cement } \\
\text { Ratio }\end{array}$} & \multirow{2}{*}{$\begin{array}{c}\text { Binder } \\
\text { Materials }\end{array}$} & \multirow{2}{*}{$\begin{array}{c}\text { Sand } \\
\text { Rate (\%) }\end{array}$} & \multicolumn{8}{|c|}{ Quantity of Concrete per Cubic Meter } \\
\hline & & & & & Water & Cement & Fly ash & Silica Fume & $\begin{array}{c}\text { Fine } \\
\text { Aggregates }\end{array}$ & $\begin{array}{c}\text { Coarse } \\
\text { Aggregates }\end{array}$ & JM-PCA & NOF-AE \\
\hline $\begin{array}{l}\text { Normal } \\
\text { concrete }\end{array}$ & 59.1 & 0.33 & 379 & 38 & 125 & 284 & 76 & 19 & 718 & 1172 & 3.411 & 0.015 \\
\hline $\begin{array}{l}\text { Pumping } \\
\text { concrete }\end{array}$ & 59.1 & 0.33 & 415 & 40.5 & 137 & 311 & 83 & 21 & 738 & 1087 & 3.735 & 0.017 \\
\hline
\end{tabular}

Note: the concrete mix proportion is calculated by the absolute volume method, and the air content is 3\%.

Table 4. Performance of two graded fly ash and silica fume concrete mixture.

\begin{tabular}{|c|c|c|c|c|c|c|c|c|}
\hline \multirow[b]{2}{*}{ Construction Method } & \multirow[b]{2}{*}{ Water-Cement Ratio } & \multirow{2}{*}{ Binder Materials $\left(\mathrm{kg} / \mathrm{m}^{3}\right)$} & \multirow{2}{*}{ Sand Rate (\%) } & \multirow{2}{*}{ Air Contents (\%) } & \multicolumn{4}{|c|}{ Slump (cm)/Loss Rate (\%) } \\
\hline & & & & & 0 & $30 \mathrm{~min}$ & $60 \mathrm{~min}$ & $90 \mathrm{~min}$ \\
\hline Normal concrete & 0.33 & 379 & 38 & 2.5 & $16.0 / 0$ & $12.8 / 20.0$ & $5.7 / 64.4$ & 1 \\
\hline Pumping concrete & 0.33 & 415 & 40.5 & 2.0 & $19.5 / 0$ & $16.0 / 17.9$ & $14.5 / 25.6$ & $12.0 / 38.5$ \\
\hline
\end{tabular}




\subsubsection{Test Method}

The test was performed according to the ring method using a high-velocity water flow abrasion-resistance apparatus as the test device, shown in Figure 3 [25]. The test mold was a cone on the outside, $30 \mathrm{~cm}$ in inner diameter and $10 \mathrm{~cm}$ in height. After the preparation, the concrete specimen was placed in the quiescent state at room temperature for $24 \mathrm{~h}$; after that, it was demolded and moved into a standard curing chamber at $20 \pm 5{ }^{\circ} \mathrm{C}$ and $>95 \%$ relative humidity for curing purpose. The specimen was soaked in water for saturation 2 day before reaching the test age and then taken out of the water, wiped and weighed for the scouring and abrasion test.

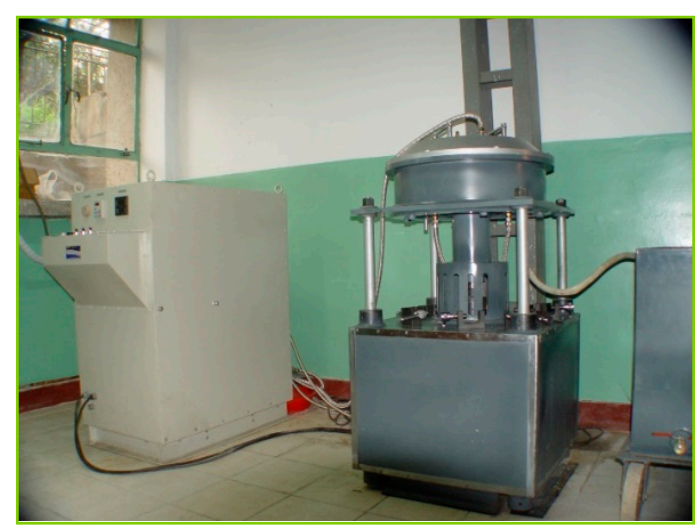

Figure 3. A high-velocity water flow abrasion-resistance apparatus.

The scouring and abrasion medium used emery with a particle size in the range of 0.4-2.0 $\mathrm{mm}$ and a sand factor of $20 \%$ (mass ratio). The water flow had a nominal flow rate in the range of $10-40 \mathrm{~m} / \mathrm{s}$ (freely adjustable) and was set at $40 \mathrm{~m} / \mathrm{s}$ in this test. The specimens in each group were subjected to repeated scouring and abrasion for three times; the cumulative scouring and abrasion time was $T$. After the test, each specimen was taken out, flushed with water, wiped and weighed again. The anti-scouring and abrasion-resistant strength of concrete was calculated using the following formula [25]:

$$
f_{a}=\frac{T A}{\Delta M}
$$

where $f_{a}$ represents the anti-scouring and abrasion-resistant strength of concrete, i.e., the time taken to scour and abrade a unit of mass on a unit area, $\mathrm{h} /\left(\mathrm{g} / \mathrm{cm}^{2}\right) ; T$ represents the cumulative scouring and abrasion time of a specimen, $\mathrm{h} ; A$ represents its scoured area, $\mathrm{cm}^{2},(A=\pi D H) ; D$ represents its inner diameter, $30 \mathrm{~cm} ; H$ represents its inner ring height, $10 \mathrm{~cm} ; \Delta M$ represents the cumulative scouring and abrasion mass during $T$ time interval, $g$.

A standard cubic specimen with an edge length of $150 \mathrm{~mm}$ was used, and each group consisted of three concrete blocks made and cured under the same conditions. The uniaxial compressive strength was expressed by the pressure per unit area when the specimen was damaged, as shown in Formula (2). The tensile strength of concrete was determined by splitting method, as shown in Formula (3).

$$
f_{c u}=\frac{F}{A}
$$

where $f_{\text {cu }}$ is the compressive strength of concrete cube (MPa), $F$ is the ultimate load $(\mathrm{N})$ and $A$ is the compression area $\left(\mathrm{mm}^{2}\right)$.

$$
f_{t s}=\frac{2 F}{\pi A}
$$

where $f_{t s}$ is splitting tensile strength of concrete (MPa), $F$ is failing load $(\mathrm{N})$ and $A$ is the area of splitting surface of specimen $\left(\mathrm{mm}^{2}\right)$. 
The dry shrinkage deformation of concrete is expressed by the shrinkage rate. The specimens of $100 \mathrm{~mm} \times 100 \mathrm{~mm} \times 500 \mathrm{~mm}$ were dried and shrank to the specified age under standard test conditions. The length of specimens before and after drying shrinkage was measured and the readings were repeated three times during each measurement. Taking the arithmetic mean value of the three measurements, the dry shrinkage rate can be calculated according to Formula (4).

$$
\varepsilon_{s t}=\frac{L_{0}-L_{t}}{L_{b}} \times 100 \%
$$

where $L_{b}$ is measuring gauge length of test piece; $L_{0}$ is the initial value of specimen length; $L_{t}$ is the length value of the test piece measured at test period $\mathrm{T}(\mathrm{mm}) ; \varepsilon_{s t}$ is the dry shrinkage rate of concrete obtained when the test period is $t$ days.

\subsection{Test Results and Discussions}

\subsubsection{Fly Ash Effect}

Figures 4 and 5 show the change trends of the compressive strength and anti-scouring and abrasion-resistant strength of concrete with the test age at different dosages of fly ash. In the process of the experiment, three groups of tests were carried out in parallel for the same measurement and the average value of the three measurements was taken in order to minimize experimental result errors.

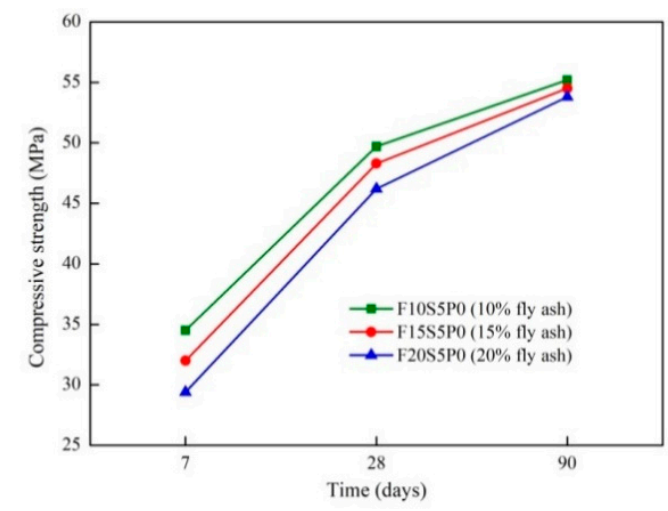

Figure 4. Effect of fly ash dosage on compressive strength of concrete.

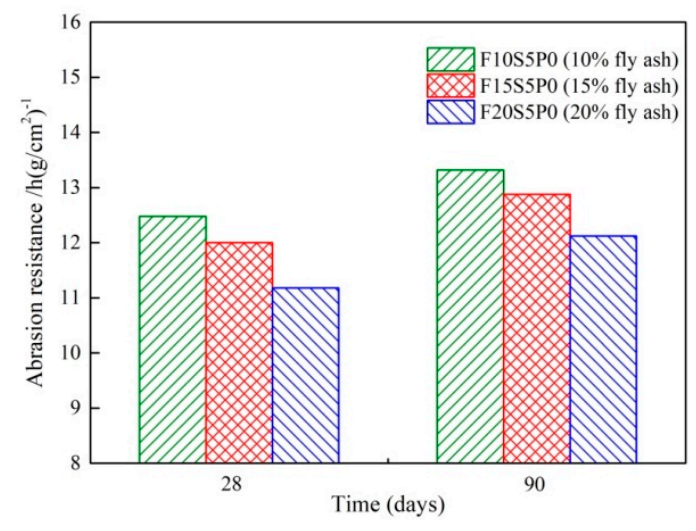

Figure 5. Effect of fly ash dosage on abrasion resistance of concrete.

As shown in Figure 4, the compressive strength of concrete decreased with increasing dosage of fly ash but increased with increasing test age. In the early stage of the test, the compressive strength of concrete increased rapidly but decreased at a relatively high dosage of fly ash. This was mainly because the failure of a large amount of fly ash particles to participate in the hydration reaction weakened the bonding between the cement paste and aggregate, which significantly reduced the compressive 
strength of concrete in the early stage. For instance, at the age of 7 day, when the dosages of fly ash were $10 \%, 15 \%$ and $20 \%$, the compressive strengths of the concrete specimen were $34.5,32.0$ and $29.4 \mathrm{MPa}$, respectively. Compared to the dosage of $10 \%$, the compressive strengths of the concrete specimen at the dosages of $15 \%$ and $20 \%$ reduced by $7.25 \%$ and $14.78 \%$, respectively. In the late stage of the test, because of the pozzolanic effect of fly ash, fly ash particles reacted with the $\mathrm{Ca}(\mathrm{OH})_{2}$ in the cement and generated calcium silicate hydrate (C-S-H) gel and calcium sulphoaluminate hydrate (C-A-S-H), which, as a cementing substance, gradually increased with increasing test age. Thus, although the strength of the concrete specimen in the early stage significantly decreased with the growth of age, the compressive strength of concrete rapidly increased in the later stage. At the test age of 90 day, when the dosages of fly ash were $10 \%, 15 \%$ and $20 \%$, the compressive strengths of the concrete specimen were $55.2,54.5$ and $53.8 \mathrm{MPa}$, respectively, suggesting that the compressive strengths of the concrete specimen at different dosages were approximately equal to each other.

The anti-scouring and abrasion-resistant strength of the concrete specimen also decreased with increasing dosage of fly ash. As shown in Figure 5, at the test age of 28 day, when the dosages of fly ash were $10 \%, 15 \%$ and $20 \%$, the anti-scouring and abrasion-resistant strengths of the concrete specimen were $12.48 \mathrm{~h}\left(\mathrm{~g} / \mathrm{cm}^{2}\right)^{-1}, 12.0 \mathrm{~h}\left(\mathrm{~g} / \mathrm{cm}^{2}\right)^{-1}$ and $11.18 \mathrm{~h}\left(\mathrm{~g} / \mathrm{cm}^{2}\right)^{-1}$, respectively. At the test age of 90 day, when the dosages of fly ash were $10 \%, 15 \%$ and $20 \%$, the anti-scouring and abrasion-resistant strengths of the concrete specimen were $13.32 \mathrm{~h}\left(\mathrm{~g} / \mathrm{cm}^{2}\right)^{-1}, 12.88 \mathrm{~h}\left(\mathrm{~g} / \mathrm{cm}^{2}\right)^{-1}$ and $12.12 \mathrm{~h}\left(\mathrm{~g} / \mathrm{cm}^{2}\right)^{-1}$, respectively. Compared to the dosage of $10 \%$, the anti-scouring and abrasion-resistant strengths of the concrete specimen at the dosages of $15 \%$ and $20 \%$ were reduced by $3.85 \%$ and $10.42 \%$ and $3.30 \%$ and $9.15 \%$, respectively.

\subsubsection{Silica Fume Effect}

Table 5 provides the results of the test on high-strength concrete performance using silica fume. Figure 6 shows the change trends of the compressive strength, anti-scouring and abrasion-resistant strength and volumetric dry shrinkage rate of concrete with test age at different dosages of silica fume $(5 \%, 7 \%$ and $9 \%)$.

Table 5. Test results of silica fume effect on concrete.

\begin{tabular}{|c|c|c|c|c|c|c|c|c|c|c|c|c|}
\hline \multirow{2}{*}{ Mixture No. } & \multirow{2}{*}{$\begin{array}{l}\text { Silica Fume } \\
\text { Content/(\%) }\end{array}$} & \multicolumn{3}{|c|}{ Compressive Strength/(MPa) } & \multicolumn{2}{|c|}{$\begin{array}{c}\text { Abrasion } \\
\text { Resistant } /\left(\mathrm{h}\left(\mathrm{g} / \mathrm{cm}^{2}\right)^{-1}\right)\end{array}$} & \multicolumn{6}{|c|}{ Volume Shrinkage/(×10-6) } \\
\hline & & 7 day & 28 day & 90 day & 28 day & 90 day & 3 day & 7 day & 14 day & 28 day & 60 day & 90 day \\
\hline F20S5P0 & 5 & 29.4 & 46.2 & 53.8 & 11.18 & 12.12 & -22 & -75 & -178 & -240 & -283 & -309 \\
\hline F20S9P0 & 9 & 32.1 & 55.3 & 61.9 & 13.74 & 14.46 & -28 & -90 & -187 & -259 & -302 & -338 \\
\hline
\end{tabular}
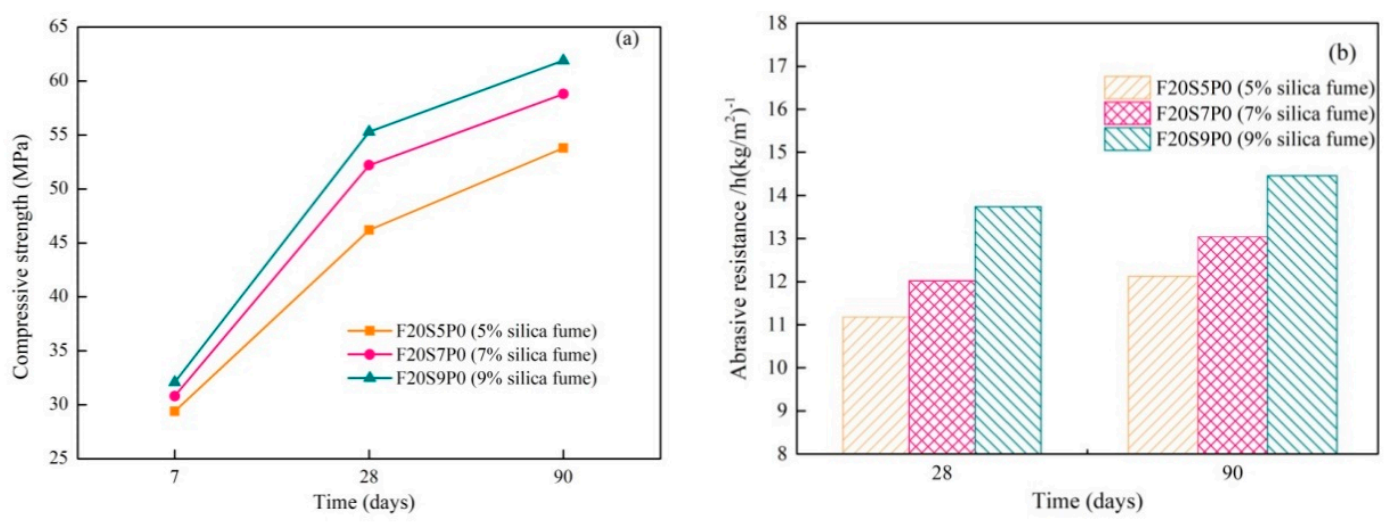

Figure 6. Cont. 


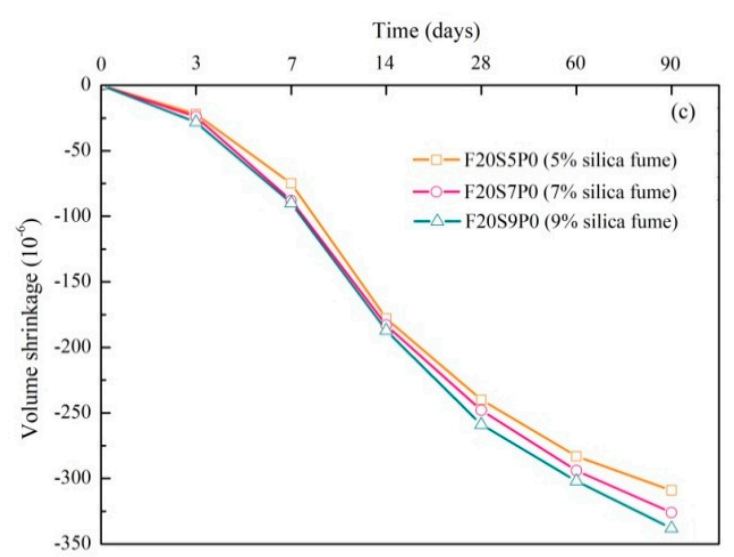

Figure 6. Effect of silica fume on concrete properties. (a) Compressive strength; (b) abrasion resistance; (c) volume shrinkage.

As shown in Figure 6a, the compressive strength of concrete increased with increasing dosage of silica fume; at the same dosage of silica fume, the increase amplitude of the compressive strength of concrete in the late stage was higher than that of the compressive strength of concrete in the early stage. At the age of 7 day, when the dosages of silica fume were $5 \%, 7 \%$ and $9 \%$, the compressive strengths of the concrete specimen were 29.4, 30.8 and $32.1 \mathrm{MPa}$, respectively. Compared to the dosage of $5 \%$, the compressive strengths of the concrete specimen at the dosages of $7 \%$ and $9 \%$ increased by $4.55 \%$ and $9.18 \%$, respectively. At the test age of 90 day, they increased by $8.50 \%$ and $15.06 \%$, respectively. This was because the ordinary concrete was loose with significant volumes inside and the cement was irregular in shape with sharp edges and corners. Under the surface tension of pore water, there would be no complete contact among particles. After adding silica fume, because of their small size and spherical shape, silica fume particles would fill in those pores, react with $\mathrm{Ca}(\mathrm{OH})_{2}$ and produce high-strength and high-stability C-S-H crystals. As a result, C-S-H crystals would block the pore canals, reduce large pores, change the internal pore structure of concrete and significantly improve its strength.

In addition, the silica fume added into concrete improved both the anti-scouring and abrasion-resistant performance and hardness of paste. The bonding status of the interface between the cement paste and aggregate could largely enhance the anti-scouring and abrasion-resistant performance of coarse aggregate and strengthen the anti-scouring and abrasion-resistant strength of concrete. In Figure 6b, at the age of 28 day, when the dosages of silica fume were 5\%, 7\% and 9\%, the anti-scouring and abrasion-resistant strengths of the concrete specimen were $11.18 \mathrm{~h}\left(\mathrm{~g} / \mathrm{cm}^{2}\right)^{-1}$, $12.02 \mathrm{~h}\left(\mathrm{~g} / \mathrm{cm}^{2}\right)^{-1}$ and $13.74 \mathrm{~h}\left(\mathrm{~g} / \mathrm{cm}^{2}\right)^{-1}$, respectively. Compared to the dosage of $5 \%$, the anti-scouring and abrasion-resistant strengths of the concrete specimen at the dosages of $7 \%$ and $9 \%$ increased by $7.51 \%$ and $22.90 \%$, respectively, and at the test age of 90 day, they increased by $7.59 \%$ and $19.30 \%$, respectively.

Doping silica fume could improve the strength performance index of concrete; however, silica fume concrete faced the problem of plastic dry shrinkage in the early stage and was extremely susceptible to shrinkage cracking. As shown in Figure $6 c$, the volumetric dry shrinkage rate of concrete increased with increasing dosage of silica fume. At the test age of 90 day, compared to the dosage of $5 \%$, the volumetric dry shrinkage rates of the concrete specimen at the dosages of $7 \%$ and $9 \%$ increased by $5.50 \%$ and $9.39 \%$, respectively. Meanwhile, due to the extremely rapid development of the early strength of silica fume concrete, the hydration heat release of concrete was extremely rapid as well, resulting in the high hydration heat-induced temperature rise of concrete, and could very easily produce a relatively high temperature stress in concrete. The easy concentration of this stress at the top of the shrinkage crack caused the crack to propagate and extend, and a penetrated crack was likely to develop. For this reason, the dosage of silica fume in concrete should be optimal to ensure the compliance of the anti-scouring and abrasion-resistant strength of concrete with engineering requirements and reduce the risks of shrinkage cracking and concrete cracking. 


\subsubsection{PVA Fiber Effect}

Table 6 provides the results of the test on high-strength concrete performance using PVA fiber. Figure 7 shows the change rules of the compressive strength, splitting tensile strength and anti-scouring and abrasion-resistant strength of concrete with test age.

Table 6. Test results of polyvinyl alcohol (PVA) fiber effect on concrete.

\begin{tabular}{|c|c|c|c|c|c|c|c|c|c|}
\hline \multirow{2}{*}{ Mixture No. } & \multirow{2}{*}{$\begin{array}{l}\text { PVA Fiber } \\
\text { Content/\% }\end{array}$} & \multicolumn{3}{|c|}{ Compressive Strength/MPa } & \multicolumn{3}{|c|}{ Split Tensile Strength/MPa } & \multicolumn{2}{|c|}{ Abrasion Resistant $/ \mathrm{h}\left(\mathrm{g} / \mathrm{cm}^{2}\right)^{-1}$} \\
\hline & & 7 day & 28 day & 90 day & 7 day & 28 day & 90 day & 28 day & 90 day \\
\hline F20S5P0.8 & 0.8 & 29.5 & 43 & 55 & 2.51 & 3.2 & 3.65 & 10.25 & 11.09 \\
\hline F20S5P0.9 & 0.9 & 30 & 43.3 & 55.8 & 2.59 & 3.28 & 3.72 & 10.36 & 11.48 \\
\hline F20S5P1.0 & 1.0 & 30.1 & 44.4 & 56.5 & 2.65 & 3.38 & 4 & 10.35 & 11.62 \\
\hline
\end{tabular}
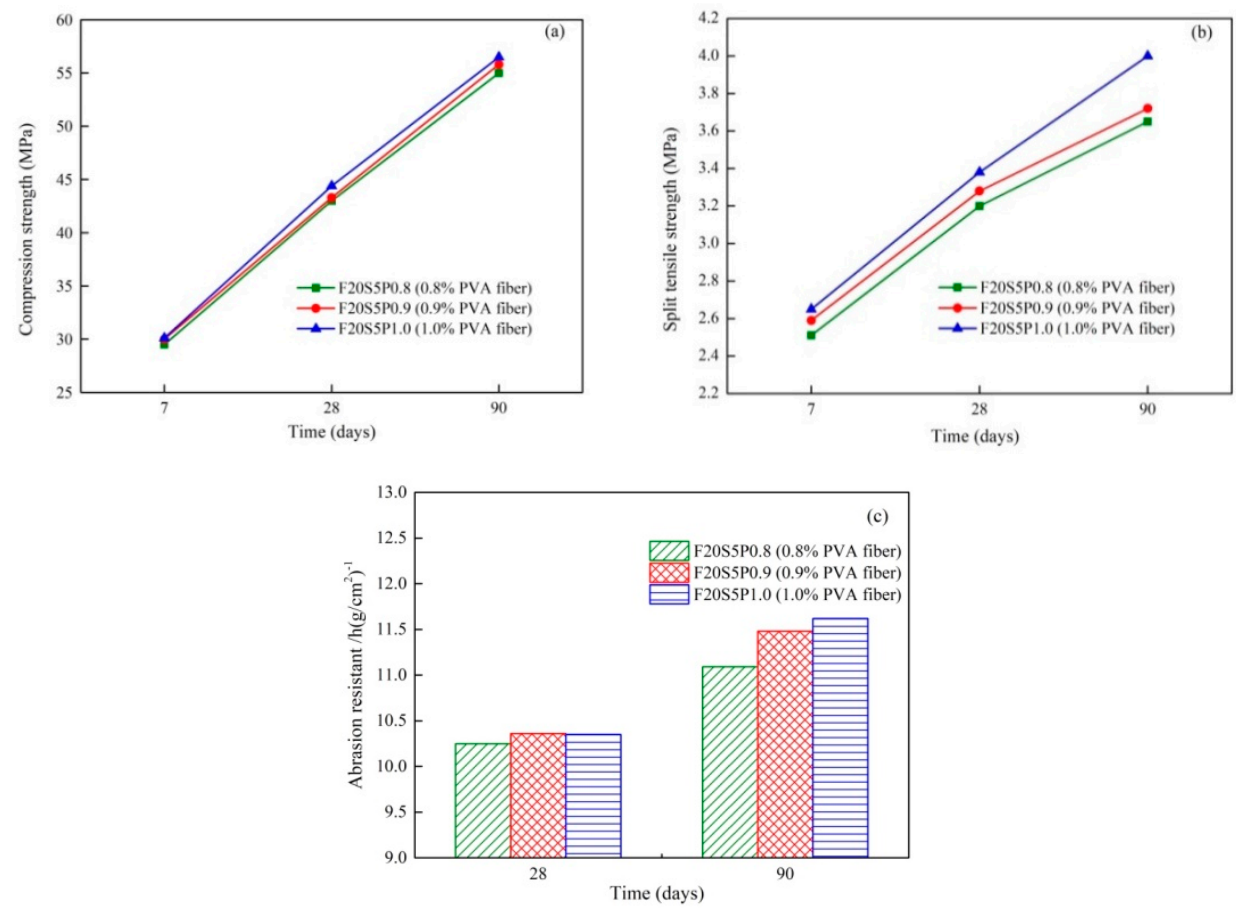

Figure 7. Effect of PVA fiber on concrete properties. (a) Compressive strength; (b) split tensile strength; (c) abrasion resistance.

As shown in Figure 7a, after doping PVA fiber into concrete, the compressive strength of concrete slightly increased with increasing dosage of PVA fiber but the change amplitude was very small. At the age of 90 day, when the dosages of PVA fiber were $0.8 \%, 0.9 \%$ and $1.0 \%$, the compressive strengths of the concrete specimen were 55.0, 55.8 and $56.5 \mathrm{MPa}$, respectively. Compared to the dosage of $0.8 \%$, the compressive strengths of the concrete specimen at the dosages of $0.9 \%$ and $1.0 \%$ increased by $1.45 \%$ and $2.73 \%$, respectively, and thus the increase amplitudes were relatively small because the dosage of PVA fiber mixed in concrete was relatively low and the PVA fiber with stable physical and chemical properties in concrete would not modify the physical or chemical properties of concrete. In brief, doping a small amount of PVA fiber in concrete would not exert any substantial effect on the compressive strength of concrete.

According to Figure $7 \mathrm{~b}$, the splitting tensile strength of concrete increased with increasing dosage of PVA fiber. At the age of 7 day, when the dosages of PVA fiber were $0.8 \%, 0.9 \%$ and $1.0 \%$, the splitting tensile strengths of the concrete specimen were 2.51, 2.59 and $2.65 \mathrm{MPa}$, respectively. Compared to the dosage of $0.8 \%$, the splitting tensile strengths of the concrete specimen at the dosages of $0.9 \%$ and $1.0 \%$ increased by $3.19 \%$ and $5.58 \%$, respectively. At the test age of 90 day, when the dosages of PVA fiber were $0.8 \%, 0.9 \%$ and $1.0 \%$, the splitting tensile strengths of the concrete specimen were $3.65,3.72$ and 
4.0 $\mathrm{MPa}$, respectively. Compared to the dosage of $0.8 \%$, the splitting tensile strengths of the concrete specimen at the dosages of $0.9 \%$ and $1.0 \%$ increased by $1.92 \%$ and $9.59 \%$, respectively. This was because the splitting tensile strength of concrete was mainly embodied in its toughness and could reflect its ability to absorb energy in failure. After a small amount of PVA fiber was mixed in concrete, due to the fibrotic meshed structure of PVA fiber and its high bonding strength with concrete matrix, when stress was transmitted from the matrix to the PVA fiber, the latter would consume energy as a result of deformation and increase the load and macroscopic deformation of the concrete component upon initial cracking. Besides, as listed in Table 3, the PVA fiber used in the test was characterized by fine extensibility, high elastic modulus and high compressive strength, indicating that once concrete began to crack, PVA fiber would bridge the gap between the crack walls and prevent the rapid propagation of the crack. In addition, PVA would be pulled out or fractured only when stress exceeded the bonding strength between the PVA fiber and matrix or the tensile strength of PVA fiber. Thus, PVA fiber could significantly improve the fracture toughness and tensile strength of concrete.

In addition, as shown in Figure 7c, the anti-scouring and abrasion-resistant strength of concrete also slightly increased with increasing mixture of the PVA fiber. At the test age of 90 day, when the mixtures of PVA fiber were $0.8 \%, 0.9 \%$ and $1.0 \%$, the anti-scouring and abrasion-resistant strengths of the concrete specimen were $11.09 \mathrm{~h}\left(\mathrm{~g} / \mathrm{cm}^{2}\right)^{-1}, 11.48 \mathrm{~h}\left(\mathrm{~g} / \mathrm{cm}^{2}\right)^{-1}$ and $11.62 \mathrm{~h}\left(\mathrm{~g} / \mathrm{cm}^{2}\right)^{-1}$, respectively. Compared to the dosage of $0.8 \%$, the anti-scouring and abrasion-resistant strengths of the concrete specimen at the dosages of $0.9 \%$ and $1.0 \%$ increased by $3.52 \%$ and $4.45 \%$, respectively. This was because after doping a suitable amount of PVA fiber in concrete, when cement solidified, PVA fiber would present a 3D irregular distribution in cement paste, form a multi-directional supporting system, effectively improve the anti-scouring and abrasion-resistant performance of the concrete member and reduce the micro-cracks induced by the shrinkage of cement matrix. Under water flow scouring and abrasion by other forces, the concrete component would always fail for a crack, and the larger the crack, the easier the failure. In this case, doping PVA fiber could effectively reduce the formation of micro-cracks and other weak links in the concrete member and thus improve the anti-scouring and abrasion-resistant performance of concrete.

\subsection{Mix Design and Concrete Performance Test}

As indicated by the test on dosage selection for fly ash, with increasing dosage of fly ash, the compressive strength, splitting tensile strength and anti-scouring and abrasion-resistant strength of concrete all decreased. With the growth of test age, due to the late-stage effect of fly ash, the concrete with a higher dosage of fly ash witnessed a faster strength increase; at the age of 90 day, the strengths of concrete at different dosages of fly ash were relatively close to each other. Given that the anti-scouring and abrasion-resistant concrete for Dagangshan Hydropower Station had a design age of 90 day, to fully utilize fly ash's advantage of faster strength increase in the late stage, it was recommended to use a dosage of $20 \%$ for fly ash. As indicated by the test on dosage selection for silica fume, with increasing dosage of silica fume, the compressive strength and anti-scouring and abrasion-resistant strength of concrete increased as well; when the dosage of silica fume increased by $2 \%$, the compressive strength of concrete increased by approximately $5 \%$. Meanwhile, with increasing dosage of silica fume, the dry shrinkage rates of concrete at different ages would increase as well; when the dosage of silica fume increased from $5 \%$ to $9 \%$, the increase in the dry shrinkage rate of concrete was within $8 \%$. To guarantee the compressive strength and anti-scouring and abrasion-resistant strength of concrete and reduce the probability of concrete cracking, it was recommended to use a dosage of $5 \%$ for silica fume. The performance test result on the concrete at different dosages of PVA fiber shows that when the dosage of PVA fiber increased from $0.8 \mathrm{~kg} / \mathrm{m}^{3}$ to $1.0 \mathrm{~kg} / \mathrm{m}^{3}$, the compressive strength, splitting tensile strength, and anti-scouring and abrasion-resistant strength of concrete gradually increased, but the increase in amplitudes was not substantial [26-31]. The test adopted the dosage of $0.9 \mathrm{~kg} / \mathrm{m}^{3}$ recommended by the manufacturer for PVA fiber. After several times of field trial mixing 
and optimal adjustment, the construction data listed in Table 7 were finally proposed for guiding field concrete casting.

Table 7. Construction mix proportion of spillway tunnel sidewall lining concrete (unit: $\mathrm{kg} / \mathrm{m}^{3}$ ).

\begin{tabular}{|c|c|c|c|c|c|c|c|c|c|c|c|c|}
\hline \multirow[b]{2}{*}{$\begin{array}{l}\text { Strength } \\
\text { Grade }\end{array}$} & \multirow[b]{2}{*}{ Grade } & \multirow[b]{2}{*}{$\begin{array}{c}\text { Water-Binder } \\
\text { Ratio }\end{array}$} & \multirow[b]{2}{*}{$\begin{array}{c}\text { Sand } \\
\text { Ratio/\% }\end{array}$} & \multirow[b]{2}{*}{$\begin{array}{l}\text { Binder } \\
\text { Materials } \\
\text { Content }\end{array}$} & \multicolumn{8}{|c|}{ Amount of Material in Each Cubic Meter of Concrete } \\
\hline & & & & & Water & Cement & Sand & Stone & Fly Ash & $\begin{array}{l}\text { Silicon } \\
\text { Powder }\end{array}$ & $\begin{array}{c}\text { Water } \\
\text { Reducing } \\
\text { Agent of } \\
\text { JM-PCA }\end{array}$ & $\begin{array}{c}\text { Air } \\
\text { Entraining } \\
\text { Agent of } \\
\text { NOF-AE }\end{array}$ \\
\hline $\mathrm{C}_{90} 50$ & Two & 0.33 & 38 & 379 & 125 & 284 & 718 & 1172 & 76 & 19 & 3.411 & 0.015 \\
\hline
\end{tabular}

Based on the basic mix proportions of fly ash and silica fume for concrete construction provided in Table 7, after field sampling, an indoor test was conducted on the concrete specimen's compressive strength, splitting tensile strength, elastic modulus, anti-scouring and abrasion-resistant strength, dry shrinkage deformation, adiabatic temperature rise and other performance parameters. The test results are listed in Table 8.

Table 8. Physical and mechanical parameters of spillway tunnel side wall lining concrete.

\begin{tabular}{|c|c|c|c|c|c|c|c|c|c|c|c|c|c|c|c|c|c|}
\hline \multirow{2}{*}{$\begin{array}{l}\text { Strength } \\
\text { Grade }\end{array}$} & \multicolumn{2}{|c|}{$\begin{array}{c}\text { Elastic } \\
\text { Modulus/GPa }\end{array}$} & \multicolumn{3}{|c|}{$\begin{array}{l}\text { Compressive } \\
\text { Strength/MPa }\end{array}$} & \multicolumn{3}{|c|}{$\begin{array}{l}\text { Split Tensile } \\
\text { Strength/MPa }\end{array}$} & \multicolumn{3}{|c|}{$\begin{array}{c}\text { Abrasive } \\
\text { Resistance } / \mathrm{h}\left(\mathrm{kg} / \mathrm{m}^{2}\right)^{-1}\end{array}$} & \multicolumn{5}{|c|}{ 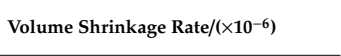 } & \multirow{2}{*}{$\begin{array}{c}\text { Thermal } \\
\text { Insulated } \\
\text { Temperature } \\
\text { Rise/ } /{ }^{\circ} \mathrm{C} \\
\end{array}$} \\
\hline & 28 day & 90 day & 7 day & 28 day & 90 day & 7 day & 28 day & 90 day & 28 day & 90 day & $\begin{array}{c}3 \\
\text { day }\end{array}$ & $\begin{array}{c}7 \\
\text { day }\end{array}$ & $\begin{array}{c}14 \\
\text { day }\end{array}$ & $\begin{array}{c}28 \\
\text { day }\end{array}$ & $\begin{array}{c}60 \\
\text { day }\end{array}$ & $\begin{array}{c}90 \\
\text { day }\end{array}$ & \\
\hline $\mathrm{C}_{90} 50$ & 26.9 & 28.7 & 34.0 & 51.7 & 60.0 & 2.51 & 3.52 & 3.81 & 6.52 & 7.96 & -12 & -71 & -156 & -253 & -323 & -359 & $\begin{array}{c}41.8 \times t /(2.278+ \\
t)\end{array}$ \\
\hline
\end{tabular}

\section{Numerical Simulation of Temperature Field}

\subsection{Model, Parameters and Schemes}

This numerical simulation of the temperature field of sidewall $\mathrm{C}_{90} 50$ concrete was performed by a 3D finite element method based on ANSYS [32]. The size of surrounding rock in the numerical model was roughly set at three times of the spillway tunnel diameter; the origin of the whole coordinate system was set at the bottom of the spillway tunnel (the direction from the upstream face to the downstream face as $y$-axis orientation; the horizontal direction perpendicular to the spillway tunnel axis as $x$-axis orientation; the upward vertical direction as $z$-axis orientation). The boundary conditions were selected as follows: the top and bottom and four sides of the surrounding rock served as the adiabatic boundaries; the construction placement section of the spillway tunnel played the role of solid-gas boundary, treated as a category-III boundary (the surface heat transfer coefficient between the boundary of the object and the surrounding fluid and the temperature of the surrounding fluid are specified). In mesh generation, hexahedral elements were adopted for surrounding rock and lining concrete, while pentahedral or tetrahedral elements were used locally as transition. The contact elements of zero thickness could be used for transmitting heat, compressive stress, shearing stress and so forth. The numerical model is shown in Figure 8. According to the site construction data and mix proportion optimization design, concrete performance test results at Dagangshan Hydropower Station and reference to similar engineering experience [33-35], the thermodynamic parameters of the $\mathrm{C}_{90} 50$ anti-scouring and abrasion-resistant concrete were used as listed in Table 9.

Table 9. Thermal parameters of abrasion resistance.

\begin{tabular}{|c|c|c|c|c|c|c|c|c|c|}
\hline \multirow{2}{*}{$\begin{array}{l}\text { Strength } \\
\text { Grade }\end{array}$} & \multirow{2}{*}{$\begin{array}{l}\text { Heat Conductivity } \\
\text { Coefficient } / \mathrm{kJ}\left(\mathrm{mh}^{\circ} \mathrm{C}\right)^{-1}\end{array}$} & \multirow{2}{*}{$\begin{array}{c}\text { Specific } \\
\left.\text { Heat } / \mathbf{k J ~}^{\circ} \mathbf{k g}^{\circ} \mathrm{C}\right)^{-1}\end{array}$} & \multirow{2}{*}{$\begin{array}{c}\text { Linear } \\
\text { Expansion } \\
\text { Coefficient } /\left({ }^{\circ} \mathrm{C}\right)^{-1}\end{array}$} & \multirow{2}{*}{$\begin{array}{l}\text { Thermal } \\
\text { Conductivity } /\left(\mathrm{m}^{2} / \mathrm{h}\right)\end{array}$} & \multirow{2}{*}{$\begin{array}{c}\text { Exothermic } \\
\text { Coefficient } /\left(\mathrm{kJ} / \mathrm{mh}^{2 \circ} \mathrm{C}\right)\end{array}$} & \multirow{2}{*}{$\begin{array}{l}\text { Thermal Insulated } \\
\text { Temperature Rise } /{ }^{\circ} \mathrm{C}\end{array}$} & \multirow{2}{*}{$\begin{array}{l}\text { Poisson's } \\
\text { Ratio }\end{array}$} & \multicolumn{2}{|c|}{$\begin{array}{c}\text { Elastic } \\
\text { Modulus/GPa }\end{array}$} \\
\hline & & & & & & & & 28 day & 90 day \\
\hline $\mathrm{C}_{90} 50$ & 6.36 & 0.93 & $8.0 \times 10^{-6}$ & 0.0027 & 42 & $41.8 \times \mathrm{t} /(2.278+\mathrm{t})$ & 0.17 & 26.9 & 28.7 \\
\hline
\end{tabular}




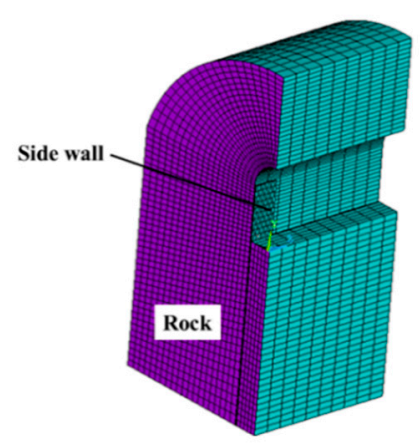

Figure 8. Meshes of simulated domains.

During casting of the sidewall $\mathrm{C}_{90} 50$ anti-scouring and abrasion-resistant concrete for the spillway tunnel, a pre-buried HDPE (High density polyethylene) plastic cooling water pipe was used for cooling purposes (inner diameter, $28 \mathrm{~mm}$; wall thickness, $2.0 \mathrm{~mm}$; thermal conductivity coefficient, $\left.1.67 \mathrm{~kJ} /\left(\mathrm{mh}^{\circ} \mathrm{C}\right)\right)$; it was laid in a uniform $S$-shaped mode, with a vertical laying interval of $1 \mathrm{~m}$. During casting, it was buried inside the concrete (Figure 9). In general, cooling water has a throughput temperature $T$ in the range of $12-17^{\circ} \mathrm{C}$, a throughput flow in the range of $1.5-1.8 \mathrm{~m}^{3} / \mathrm{h}$ and a throughput duration of no less than 7 day. The water flow should be continuous. In this numerical simulation, seven working conditions were introduced for comparison (i.e., absence of cooling water, throughput flow at $3.5 \mathrm{~m}^{3} / \mathrm{h}$ within $1-2$ day after casting, throughput flow of $17^{\circ} \mathrm{C}$ cooling water at $1.5 \mathrm{~m}^{3} / \mathrm{h}$ or $1.8 \mathrm{~m}^{3} / \mathrm{h}$ within 3-7 day and so forth); the change rules of the temperature field of $\mathrm{C}_{90} 50$ anti-scouring and abrasion-resistant concrete were obtained within a uniform simulation duration of 30 day.

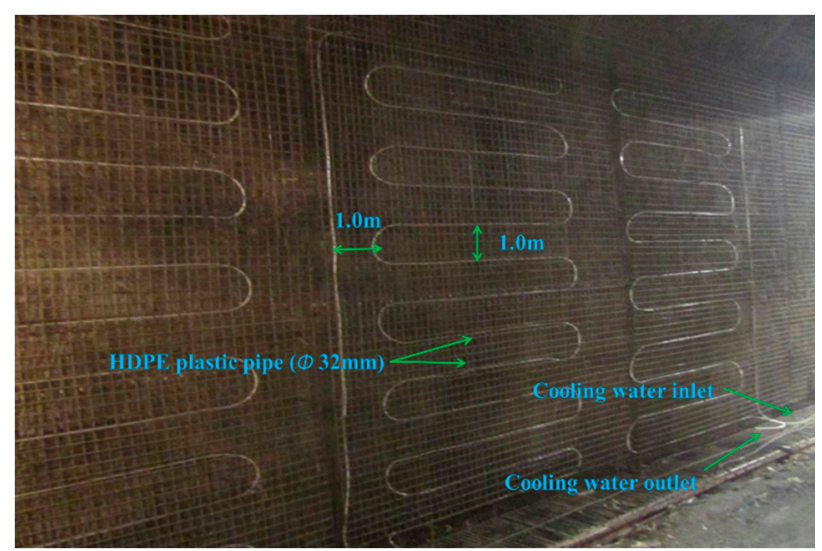

Figure 9. Layout of the cooling pipes.

\subsection{Analysis of Numerical Simulation Results}

When analyzing the results from the numerical simulation of temperature control on the lining concrete for Dagangshan Spillway Tunnel, mainly the temperature change of the geometric center of the sidewall lining concrete was selected for a comparative analysis, and statistics were made on the highest temperature, the maximum temperature difference and other characteristic parameters of the point inside the concrete under various calculation conditions, as detailed in Table 10. Figure 10 shows the variation of the highest temperature over time inside the concrete at different cooling water temperatures and different throughput flows. 
Table 10. Numerical simulation results of the highest temperature and maximum temperature difference of the sidewall lining concrete.

\begin{tabular}{|c|c|c|c|c|c|c|c|c|c|}
\hline \multirow{3}{*}{ Schemes } & \multicolumn{6}{|c|}{ Water Cooling } & \multirow{3}{*}{$\begin{array}{c}\text { Casting } \\
\text { Temperature } /{ }^{\circ} \mathrm{C}\end{array}$} & \multirow{3}{*}{$\begin{array}{c}\text { Highest } \\
\text { Temperature/ } /{ }^{\circ} \mathrm{C}\end{array}$} & \multirow{3}{*}{$\begin{array}{c}\text { Maximum } \\
\text { Temperature } \\
\text { Difference } /{ }^{\circ} \mathrm{C}\end{array}$} \\
\hline & \multicolumn{3}{|c|}{ The First Stage } & \multicolumn{3}{|c|}{ The Second Stage } & & & \\
\hline & \multicolumn{2}{|c|}{ Temperature $/{ }^{\circ} \mathrm{C}$ Flow $/\left(\mathrm{m}^{3} / \mathrm{h}\right)$} & $\begin{array}{c}\text { Duration/day } \\
/\end{array}$ & \multicolumn{2}{|c|}{ Temperature $/{ }^{\circ} \mathrm{C}$ Flow $/\left(\mathrm{m}^{3} / \mathrm{h}\right)$} & $\frac{\text { Duration/Day }}{/}$ & & & \\
\hline 2 & 17 & 3.5 & $0 \sim 2$ & 17 & 1.8 & $3 \sim 7$ & 17 & 39.07 & 16.29 \\
\hline 3 & 17 & 3.5 & $0 \sim 2$ & 17 & 1.5 & $3 \sim 7$ & 17 & 39.07 & 19.35 \\
\hline 4 & 15 & 3.5 & $0 \sim 2$ & 17 & 1.5 & $3 \sim 7$ & 17 & 34.35 & 15.27 \\
\hline 5 & 15 & 3.5 & $0 \sim 2$ & 17 & 1.8 & $3 \sim 7$ & 17 & 34.35 & 13.31 \\
\hline
\end{tabular}

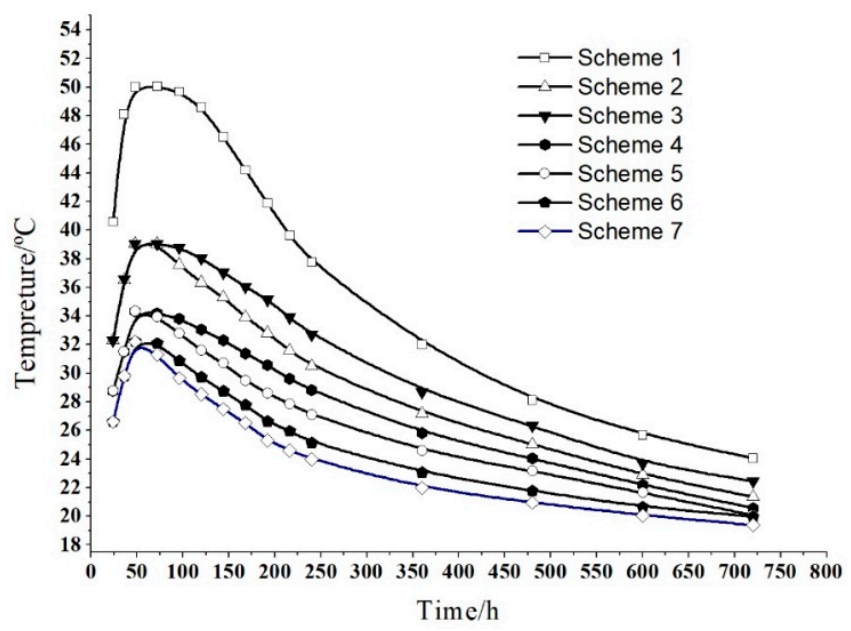

Figure 10. The maximum temperature duration curve of concrete under different schemes.

Through comparing the temperature variation of the typical points in the sidewall $\mathrm{C}_{90} 50$ anti-scouring and abrasion-resistant concrete under different temperature control schemes, the following conclusions could be drawn:

(1) During the casting of sidewall $\mathrm{C}_{90} 50$ anti-scouring and abrasion-resistant concrete, the temperature inside the concrete roughly experienced two stages, i.e., hydration heat-induced temperature rise and temperature drop. In the initial stage of casting, because of the hydration heat action of cement, the temperature inside the concrete rose up abruptly and reached its peak roughly 2 day after casting. After that, on account of throughput cooling and other temperature control measures, the temperature inside the concrete began to drop. Considering that the peak temperature of concrete occurred roughly 2 day after casting, it was suggested that the early-stage throughput cooling be strengthened during construction to guarantee the cooling effect of concrete.

(2) As shown in Figure 10, under the same throughput flow conditions, throughput temperature declined from 17 to $12{ }^{\circ} \mathrm{C}$, accompanied by the downward movement of the duration curve of the temperature inside the concrete; the peak temperature declined from 39.07 to $32.31{ }^{\circ} \mathrm{C}$; the maximum temperature difference dropped from 19.35 to $14.44{ }^{\circ} \mathrm{C}$, manifesting a good negative correlation. This suggested that throughput temperature was an important factor affecting the cooling effect of the cast concrete and that a relatively low throughput temperature should be adopted under suitable conditions during construction to enhance the cooling effect of concrete.

(3) According to Figure 10, under the same throughput temperature conditions, when throughput flow increased from 1.5 to $1.8 \mathrm{~m}^{3} / \mathrm{h}$, the duration curve of the temperature inside concrete would correspondingly move downward, accompanied by the corresponding decrease in the maximum temperature difference. This suggested that throughput flow was another important factor affecting the cooling effect of the cast concrete and that there was an obvious positive correlation between such a cooling effect and the rate of the throughput flow, i.e., high throughput flow could more rapidly remove the hydration heat of concrete and create a quick cooling effect. 


\section{Analysis of Temperature Monitoring Data}

The casting of sidewall $\mathrm{C}_{90} 50$ silica fume concrete lining was carried out by using a novel self-developed tunnel steel trolley. The trolley consists of a frame system, template system, vertical reciprocating lift system, automatic concrete spreading system, hydraulic running system, suspension system, shifting and jacking system, etc. When casting sidewall concrete, the vertical lift system of the trolley first lifts the stock bin with normal concrete to the predetermined height. After that, the electric hoist is enabled to drag the stock bin until it is right above the concrete spreader. Finally, both the concrete spreader and the stock bin are enabled so that the concrete spreader transports concrete to the inner side of the template and thus realizes the automatic casting of sidewall normal lining concrete. The field construction is shown in Figure 11.

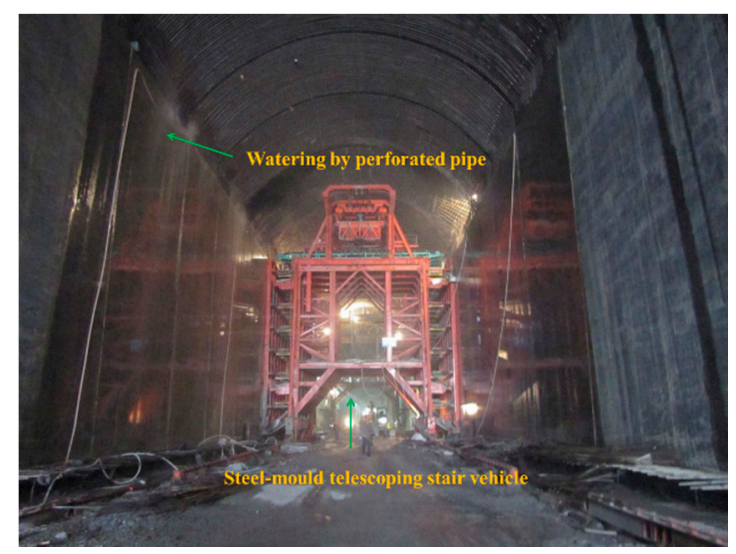

Figure 11. Construction of spillway tunnel sidewall lining concrete.

Based on the performance test and numerical simulation results, in the construction of sidewall $\mathrm{C}_{90} 50$ silica fume concrete lining, the cooling measure of "early-throughput, high-flow and short-duration" was used for temperature control and crack prevention. In the view of the concentrated hydration heat and high heat production of $\mathrm{C}_{90} 50$ silica fume concrete in the early stage, it is suggested that the cooling measure of condition seven in the numerical simulation be adopted during construction to avoid excessively fast temperature rise of lining concrete. During the casting process and over 1-2 day after casting, $12{ }^{\circ} \mathrm{C}$ "high-flow and low-temperature" cooling water was guided in at a flow of approximately $3.5 \mathrm{~m}^{3} / \mathrm{h}$. Within $3-7$ day after casting, because of the template removal, with increasing radiating surface and reducing template constraints the temperature dropped abruptly. In contrast, the temperature inside the concrete still maintained a rising trend, resulting in a relatively large internal/external temperature difference. Under the action of expansion caused by heat and contraction caused by cold, tensile stress increased rapidly, making it susceptible to temperature cracking. To avoid excessively high peak temperature and excessively large internal/external temperature difference for lining concrete, during construction, $17^{\circ} \mathrm{C}$ river water at a flow of $1.8 \mathrm{~m}^{3} / \mathrm{h}$ was guided in, and the $8 \#$ iron wire hooks with length of $20 \mathrm{~cm}$ were pre-buried at the top of the sidewall at intervals of $1 \mathrm{~m}$; after sidewall demolding, the PVC (polyvinyl chloride) perforated pipes were hung on the pre-buried iron wire hooks and the water from a cooling water pipe was used to supply normal flowing water on the concrete surface for curing purposes. After 7 day, the temperature inside the concrete basically began to decrease over time. To avoid excessively fast cooling of concrete, cooling water should be suspended and surface flowing water alone could be sufficient for the cooling purpose.

Silica fume concrete is susceptible to early-stage plastic cracking; when the concrete surface is observed to turn white or the surface water evaporation rate was $>0.5 \mathrm{~kg} /\left(\mathrm{m}^{3} \mathrm{~h}\right)$, a wind shield should be used for screening and spraying should be used to maintain a necessary humidity level on the concrete surface. In low-temperature seasons or in the case of a sudden drop in air temperature, 
the demolding time should be properly postponed; in particular, demolding should be avoided in cold evenings, otherwise concrete may crack due to a large internal/external temperature difference. After demolding of fresh concrete, the transverse joint plane should be immediately covered with thermal insulation materials.

In the process of concrete casting, resistance thermometers were buried inside the concrete for real-time monitoring of concrete temperature. To be specific, for the concrete of each placement section, thermometers were buried alternatively on the left/right side and arranged at the centers of the placement sections and $4-5 \mathrm{~m}$ in height from the bottom plate $(\sim 6 \mathrm{~cm}$ from the concrete surface), as shown in Figure 12. In the first three days, the measurement interval of fresh concrete was less than $8 \mathrm{~h}$ and could be increased to $12 \mathrm{~h}$ afterwards and the measurement duration lasted for no less than 28 day. The sidewall was buried with a total of 127 thermometers, 122 of which performed well until the end of the monitoring work, with a survival rate of $96.1 \%$. The temperature monitoring results are listed in Table 11.

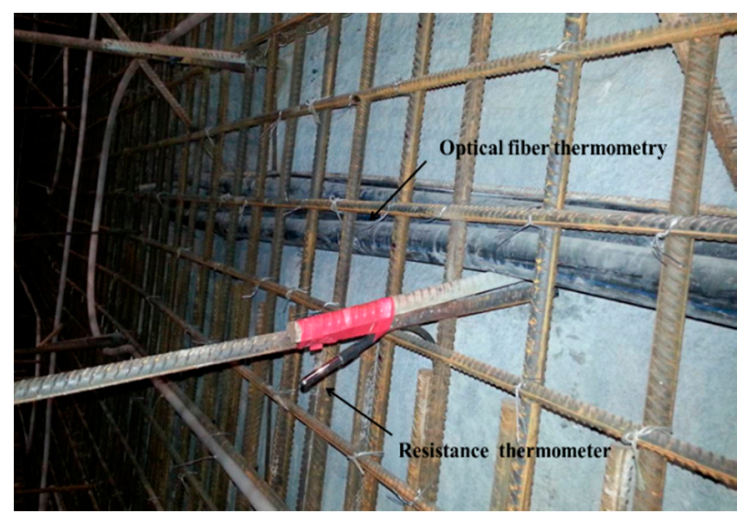

Figure 12. Layout of embedded temperature monitoring instrument.

Table 11. Temperature monitoring results of spillway side wall.

\begin{tabular}{|c|c|c|c|c|c|c|}
\hline \multirow{2}{*}{$\begin{array}{c}\text { Stake } \\
\text { Number/m }\end{array}$} & \multirow{2}{*}{$\begin{array}{l}\text { Number of } \\
\text { Resistive } \\
\text { Thermometer }\end{array}$} & \multirow{2}{*}{$\begin{array}{c}\text { Highest } \\
\text { Temperature } /{ }^{\circ} \mathrm{C}\end{array}$} & \multirow{2}{*}{$\begin{array}{c}\text { Average } \\
\text { Maximum } \\
\text { Temperature } /{ }^{\circ} \mathrm{C} \\
\end{array}$} & \multirow{2}{*}{$\begin{array}{c}\text { Permissible } \\
\text { Maximum } \\
\text { Temperature } /{ }^{\circ} \mathrm{C}\end{array}$} & \multicolumn{2}{|c|}{$\begin{array}{c}\text { Analysis of Temperature } \\
\text { Control Effect }\end{array}$} \\
\hline & & & & & Qualified Numbers & Pass Rate/\% \\
\hline $\begin{array}{l}0+000.00 \sim 0 \\
+120.00 \mathrm{~m}\end{array}$ & 14 & 36.7 & 32.05 & 36 & 13 & 92.86 \\
\hline $\begin{array}{l}0+120.00 \sim 1 \\
+037.71 \mathrm{~m}\end{array}$ & 110 & 35.8 & 33.60 & 34 & 101 & 91.82 \\
\hline $\begin{array}{l}1+037.71 \sim 1 \\
+075.50 \mathrm{~m}\end{array}$ & 3 & 33.65 & 33.47 & 36 & 3 & 100 \\
\hline
\end{tabular}

According to the relevant standards, the maximum permissible temperature inside concrete is $34^{\circ} \mathrm{C}$ and the maximum temperature difference is $25^{\circ} \mathrm{C}$. As listed in Table 9, the average highest temperatures of the concrete measured in the sidewall's transition section from $0+000.00-0+120.00 \mathrm{~m}$, standard section from $0+120.00$ to $1+037.71 \mathrm{~m}$ and transition section from $1+037.71$ to $1+075.50 \mathrm{~m}$ were 32.05 , 33.60 and $33.47^{\circ} \mathrm{C}$, respectively, slightly higher than those calculated under working condition seven from the numerical simulation but all within the permissible range. The measured peak temperature was reached roughly 2 day after casting, similar to the calculation results, as shown in Figure 13. To sum up, the change rules of the temperature field obtained through numerical simulation were relatively consistent with the measured results, and the overall temperature control monitoring of the sidewall lining concrete had a qualification rate of $>91 \%$, suggesting that the temperature control and crack prevention measures proposed in this study were satisfactory for controlling the temperature. 


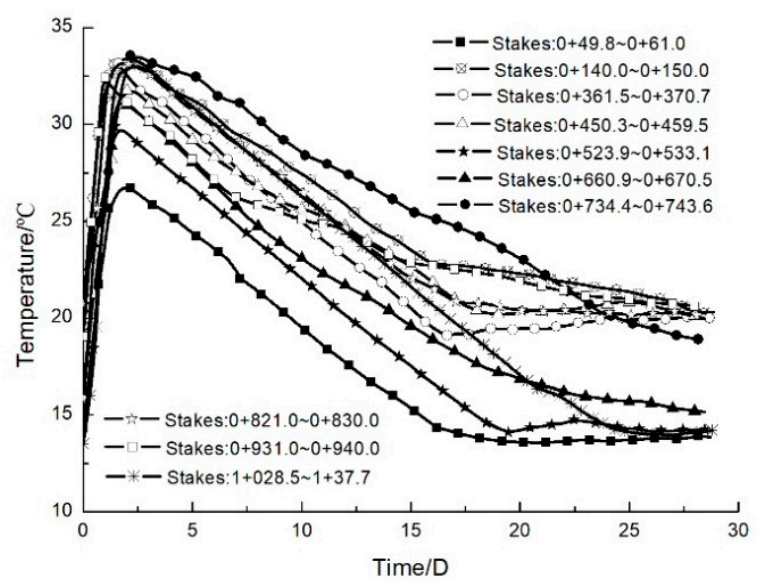

Figure 13. Temperature variation curve of concrete at typical side wall stake number.

Both the calculation and monitoring results indicated that concrete temperature generally would reach a peak level 2 day after casting and that the placing temperature of concrete exerted an obvious effect on its final highest temperature. Therefore, strictly controlling the placing temperature of concrete during construction is necessary. During the numerical simulation, the temperature of concrete was assumed to be $17^{\circ} \mathrm{C}$ during casting; however, in the course of actual construction, the casting temperature was subjected to changes and fluctuations due to multiple factors. In the view of this, efforts should be made during construction for thermal insulation during concrete transport, e.g., improving the transport system and increasing the transport efficiency. Furthermore, concrete casting during high-temperature should be avoided. In addition, it is also necessary to adopt spraying and other measures to keep placement sections in the moisturized state and reduce their ambient temperature. The maximum thickness the cast layers should also be properly controlled. In the numerical simulation, surface spraying cooling or other measures are not considered and this might be the reason that the highest temperature of concrete calculated at the age of 30 day was slightly higher than those of the monitoring results. In short, the assumptions made for the numerical simulation and the uncertain factors existing in the field construction gave rise to some differences between the calculation and field monitoring. However, they followed similar change trends over time and the results provided important implications for selection of rational engineering measures for temperature control.

\section{Conclusions}

Due to the characteristics of high water head, high velocity, large discharge and complex shape, as well as the erosion of sediment and frequent use, there are bound to be higher requirements for the material performance, pouring construction technology and temperature control of concrete for the large-scale spillway tunnel. In order to meet the requirements of erosion resistance and wear resistance of the spillway tunnel, $\mathrm{C}_{90} 50$ silica fume concrete is used for the lining of the side wall and bottom plate of the tunnel. The hydration heat is concentrated and it is easy to produce temperature cracks. Therefore, strict comprehensive temperature control measures should be taken during construction to avoid concrete cracking due to a large temperature difference between inside and outside. The above-mentioned concrete anti-erosion and wear resistance and temperature control and crack prevention are two major problems faced by large-scale spillway tunnel projects and they are closely related and mutually affected. Therefore, the anti-scouring and abrasion resistance and temperature control of $\mathrm{C}_{90} 50$ silica fume concrete were studied.

(1) The doping of fly ash, silica fume, PVA fiber and other auxiliary cementing materials indicated that (a) fly ash with a dosage of $20 \%$ could reduce water consumption and micro-cracks via its "morphological effect"; (b) silica fume with a dosage of 5\% could improve the early strength of cement concrete and make up for the strength loss caused by the fly ash; (c) PVA fiber with the dosage of 
$0.9 \mathrm{~kg} / \mathrm{m}^{3}$ could enhance the concrete durability. The doping of these three additives can increase both the strength and abrasion resistance of concrete.

(2) The peak temperature of concrete occurred roughly 2 day after casting. Properly strengthening the early-stage throughput, increasing throughput flow and decreasing cooling water temperature could achieve a satisfactory cooling effect. This study proposed a new temperature control and crack prevention measure, i.e., the "early-throughput, high-flow and short-duration" cooling strategy, which proved to be effective in reducing the maximum temperature rise inside the concrete. In the casting process, within 1-2 day after casting, cooling water at roughly $12{ }^{\circ} \mathrm{C}$ was guided in at a flow of approximately $3.5 \mathrm{~m}^{3} / \mathrm{h}$; within $3-7$ day after casting, river water at roughly $17^{\circ} \mathrm{C}$ was guided in at a flow of approximately $1.8 \mathrm{~m}^{3} / \mathrm{h} ; 7$ day later, using surface flowing water alone for curing could achieve the cooling effect. The field temperature monitoring data indicated that the temperature of the sidewall lining concrete had a qualification rate of $>91 \%$, suggesting that the temperature control and crack prevention measures can effectively reduce the maximum temperature rise inside the concrete and achieve a satisfactory temperature control effect.

(3) Through comprehensively utilizing the optimal mix proportion design, complex-curved novel template, self-propelled steel trolley, throughput cooling and other quality control measures, this paper guaranteed the construction quality of anti-scouring and abrasion-resistant concrete for the spillway tunnel and the fine shape control, smooth and flat surface and satisfactory crack control of cast concrete. The Dagangshan Spillway Tunnel began to take part in the flood discharge of the Dagangshan Reservoir in flood seasons in July 2015; at the end of 2015, its cumulative flood discharge duration reached $1784 \mathrm{~h}$; at the end of December 2016, the cumulative running hours of the spillway tunnel reached $2690 \mathrm{~h}$. Its annual average service frequency exceeded $2000 \mathrm{~h} / \mathrm{a}$, the highest among the same-type hydropower stations in China. According to the results of the inspection over the spillway tunnel after two years of frequent use, the concrete surface was as smooth as a mirror, without any obvious scouring trace, pot hole or crack failure.

Author Contributions: Conceptualization, Q.Y. and H.L.; methodology, Q.Y. and F.W.; software, Q.Y. and F.W.; validation, S.Q., X.Y. and H.L.; resources, X.Y. and H.L.; writing-original draft preparation, Q.Y., S.Q. and F.W.; writing - review and editing, Q.Y., S.Q. and H.L.; visualization, Q.Y. and F.W.; funding acquisition, Q.Y. and H.L. All authors have read and agreed to the published version of the manuscript.

Funding: This study was supported financially by the National Key R\&D Program of China (grant no. 2018YFC1508501, 2018YFC1505402), National Natural Science Foundation of China (grant no. 51809188).

Acknowledgments: Special thanks to China water resources and Hydropower Bureau 7 Co., Ltd. and Guodian Dadu River Dagangshan Hydropower Development Co., Ltd. for providing and supporting mix proportion of concrete materials and monitoring data.

Conflicts of Interest: The authors declare no conflict of interest.

\section{References}

1. Turk, K.; Karatas, M. Abrasion Resistance and Mechanical Properties of Self-Compacting Concrete with Different Dosages of Fly Ash/Silica Fume. Indian J. Eng. Mater. Sci. 2011, 18, 49-60.

2. Naik, T.R.; Singh, S.S.; Hossain, M.M. Abrasion resistance of high-strength concrete made with class C fly ash. Mater. J. 1995, 92, 649-659.

3. Ukita, K.; Shigematsu, S.; Ishic, M. Improvements in the properties of concrete utilizing classified fly ash. In Proceedings of the CANMET/ACI Third International Conference on the Use of Fly Ash, Silica Fume, Slag, and Natural Pozzolana in Concrete, Trondheim, Norway, 18-23 June 1989; pp. 219-240.

4. Siddique, R. Effect of fine aggregate replacement with Class F fly ash on the abrasion resistance of concrete. Cem. Concr. Res. 2003, 33, 1877-1881. [CrossRef]

5. Yen, T.; Hsu, T.-H.; Liu, Y.-W.; Chen, S.-H. Influence of class F fly ash on the abrasion-Erosion resistance of high-strength concrete. Constr. Build. Mater. 2007, 21, 458-463. [CrossRef]

6. Guo, R.; Nian, T.; Li, P.; Fu, J.; Guo, H. Anti-erosion performance of asphalt pavement with a sub-base of cement-treated mixtures. J. Constr. Build. Mater. 2019, 223, 278-287. [CrossRef] 
7. Liu, J.; Li, X.; Saffari, P.; Liang, Q.; Li, L.; Chen, W. Developing a Polypropylene Fabric, Silica Fume, and Redispersible Emulsion Powder Cementitious Composite for Dynamic Water Environment. Polymers 2019, 11, 47. [CrossRef]

8. Zhang, Y.; Wang, S.; Zhang, B.; Hou, D.; Li, H.; Li, L.; Wang, J.; Lin, C. A preliminary investigation of the properties of potassium magnesium phosphate cement-based grouts mixed with fly ash, water glass and bentonite. Constr. Build. Mater. 2020, 237, 117501. [CrossRef]

9. Ghafoori, N.; Diawara, H. Abrasion resistance of fine aggregate-replaced silica fume concrete. Aci Mater. J. 1999, 96, 559-567.

10. Shi, Z.Q.; Chung, D.D.L. Improving the abrasion resistance of mortar by adding latex and carbon fibers. Cem. Concr. Res. 1997, 27, 1149-1153. [CrossRef]

11. Liu, Y.W. Improving the abrasion resistance of hydraulic-concrete containing surface crack by adding silica fume. Constr. Build. Mater. 2007, 21, 972-977. [CrossRef]

12. Sonebi, M.; Khayat, K.H. Testing abrasion resistance of high-strength concrete. Cem. Concr. Aggreg. 2001, 23, $34-43$.

13. Nanni, A. Abrasion resistance of roller-compacted concrete. Aci Mater. J. 1989, 86, 559-565.

14. Siddique, R.; Kapoor, K.; Kadri, E.H.; Bennacer, R. Effect of polyester fibers on the compressive strength and abrasion resistance of HVFA concrete. Constr. Build. Mater. 2012, 29, 270-278. [CrossRef]

15. Gong, C.; Ding, W.; Mosalam, K.M.; Günay, S.; Soga, K. Comparison of the structural behavior of reinforced concrete and steel fiber reinforced concrete tunnel segmental joints. Tunnelling Undergr. Space Technol. 2017, 68, 38-57. [CrossRef]

16. Fang, C.Y.; Duan, Y.H. Analysis of temperature and thermal stresses observations on concrete lining of water delivery tunnel of Three Gorges Project permanent shiplock. Eng. J. Wuhan Univ. 2003, 36, 30-34.

17. Duan, Y.H.; Fang, C.Y.; Fan, Q.X.; Peng, J.Y. Study on field temperature experiment for concrete lining of water-conveying tunnel of permanent shiplock in Three Gorges Project. Chin. J. Rock Mech. Eng. 2006, 25, 129-135.

18. Wang, Y.; Duan, Y.H.; Huang, J.S.; Thong-Fa, C.H. Temperature control study on lining concrete of conveyance tunnel of permanent shiplock at Three Gorges Project. Eng. J. Wuhan Univ. 2001, 34, 32-36.

19. Duan, Y.L.; Zhou, R. The simulation and analysis of thermal effect in Xiaolangdi divertion tunnel during construction. J. Hydroelectr. Eng. 2005, 24, 50-54.

20. Wu, J.G.; Duan, Y.H. Cooling temperation control study on lining concrete of diversion tunnel side wall of Xiluodu power station. China Rural Water Hydropower 2007, 9, 96-99.

21. Guo, J.; Duan, Y.H. Study on cooling effect of different thickness lining concrete of Xiluodu power station diversion tunnel. China Rural Water Hydropower 2008, 12, 119-122.

22. Chen, Q.; Duan, Y.H. Influence of temperature in tunnel and surrounding rock on temperature and thermal stress of lining concrete of flood discharge tunnel. Rock Soil Mech. 2010, 31, 986-992.

23. Feng, J.G.; Duan, Y.H.; Xiang, G.X. Study on influence of concrete thermal characteristics on temperature and thermal stress of lining concrete of spillway. Water Resour. Power 2010, 28, 82-85, 173.

24. Zhao, L.; Feng, Y.; Duan, Y.H.; Liu, Q.X.; Li, C. Study on the development of lining concrete cracks of Sanbanxi spillway tunnel. Water Power 2011, 37, 35-38, 67.

25. Nanjing Water Conservancy Research Institute. DL/T 5150-2017, Test Code for Hydraulic Concrete; National Energy Board: Beijing, China, 2017.

26. Shenyang Municipal Group Company. GB/T 35843-2018, Test Method of Fiber Content of Fiber Reinforced Concrete and Its Products; General Administration of Quality Supervision, Inspection and Quarantine of the People's Republic of China and China National Standardization Administration: Beijing, China, 2018.

27. China Academy of Building Materials Science. GB/T 1596-2017, Fly Ash Used for Cement and Concrete; General Administration of Quality Supervision, Inspection and Quarantine of the People's Republic of China and China National Standardization Administration: Beijing, China, 2017.

28. Changjiang Academy of Sciences, Changjiang Water Resources Commission. DL/T 5055-2007, Technical Specification of Fly Ash for Use in Hydraulic Concrete; Development and Reform Commission of the people's Republic of China: Beijing, China, 2007.

29. China Academy of Water Resources and Hydropower. SL 352-2006, Test Code for Hydraulic Concrete; Ministry of Water Resources of the People's Republic of China: Beijing, China, 2006. 
30. Nanjing Water Conservancy Research Institute. DL/T 5207-2005, Technical Specification for Abrasion and Cavitation Resistance of Concrete of Hydraulic Structures; Development and Reform Commission of the people's Republic of China: Beijing, China, 2005.

31. Nanjing Water Conservancy Research Institute. DL/T 5100-2014, Technical Code for Chemical Admixtures for Hydraulic Concrete; National Energy Board: Beijing, China, 2014.

32. Trong, C.N.; Viet, C.M.; Xuan, B.L. Temperature distribution in concrete structure under the action of fire using Ansys software. E3S Web Conf. 2019, 91, 02010. [CrossRef]

33. Liu, Q.; Yang, J.; Liao, G. Temperature control design of high strength lining concrete for large spillway tunnel of Xiluodu Hydropower Station. Hydropower Station Des. 2011, 27, 67-70.

34. Si, Z.; Li, S.Y.; Chen, Y.L.; Yang, J. Research on thermal effect and temperature control measures for crack prevention of spillway tunnel concrete lining. J. Northwest A F Univ. 2011, 39, 211-218.

35. Li, S.Q.; Ao, X.; Li, F. Temperature Control and Crack Prevention for the Lining Concreteof Diversion Tunnel of Xiluodu Project. J. Yangtze River Entific Res. Inst. 2014, 31, 97-100.

Publisher's Note: MDPI stays neutral with regard to jurisdictional claims in published maps and institutional affiliations.

(C) 2020 by the authors. Licensee MDPI, Basel, Switzerland. This article is an open access article distributed under the terms and conditions of the Creative Commons Attribution (CC BY) license (http://creativecommons.org/licenses/by/4.0/). 